\title{
Analysis of Click Bait Phenomena in Indonesia Online News Media: Tribunnews.com with News Value
}

\author{
Elvia Devina \\ Communication Department \\ Bina Nusantara University \\ Jakarta, Indonesia \\ elvia_devina@yahoo.com
}

\author{
Rahmat Edi Irawan \\ Communication Department \\ Bina Nusantara University \\ Jakarta, Indonesia \\ reirawan@yahoo.co.id
}

\begin{abstract}
The purpose of this study is to find out how many news value elements are used in the article in the celebrity column that uses the click bait phenomenon in the tribunnews.com media. The research method used is descriptive quantitative content analysis. The data analysis of this study was conducted by analysing the results of nine articles obtained by random sampling. The results achieved in this study indicate that the calculation found the highest news value element contained in article number one and article number four where the two articles use five elements of news value. The conclusion of this study is that tribunnews.com uses five news items of news values in writing each article.
\end{abstract}

Keywords: Click Bait, News Value, Content Analysis, Quantitative, New Media

\section{INTRODUCTION}

In digital era, many people in Indonesia can easily access the Internet network, based on a survey conducted by APJII (Association of Internet Service Providers Indonesia), there are 132.7 million Internet users in Indonesia. The device used by Indonesian people to access the Internet is mobile phone or computer. This is proven from the survey conducted by APJII (seen in Figure 1) that 63.1 million Indonesians access the internet via mobile phones, 22.2 million Indonesians access the internet via computer and 67.2 million Indonesians access the internet via mobile phones and computer.

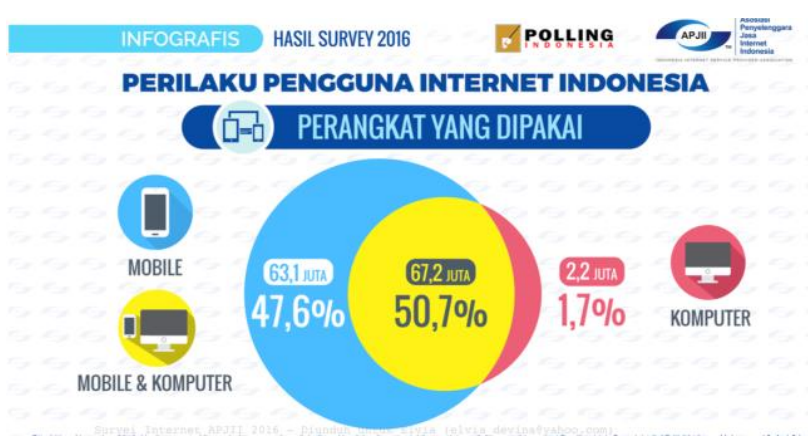

Figure 1 Internet usage in Indonesia, 2016

Based on the case, it encourages the emergence of online news portals to provide information to the public such as Detik.com, Liputan6.com, Tribunnews.com, Kompas.com, and merdeka.com. The presence of online news portal is certainly welcomed by Indonesian people, because the survey shows that there are 127.9 million Indonesian people who use Internet for news reading purpose.

Although online news portals are considered practical in providing information, but with the emergence of click bait phenomena used in online news portal in making headlines [1], this certainly raises several problems. First, the community considers click bait is a strategy used by online media aiming to attract visitors to click on the web page link [2]. It is certainly used in some media and not only in Indonesian media only. Even in the United States media such as Buzfeed and Mail Online use the click bait strategy to get millions of people to click on the articles created by both media [3]. Second, click bait is considered killing the foundations of the journalistic world because the news headline shown does not match the content of the news. Third, by using click bait, people have the view that the media produces fake news. It is then encourages the assumption that journalists produce unimportant news.

With the emergence of the problems above, a question is raised; is it true that the use of click bait push online news portal to generate unnecessary or not quality news? Therefore, in order to know whether a news is unimportant or not qualified, the researcher will relate it with news value.

The news value is the basis or benchmark in journalism world, because the news value is used as a set of criteria to assist journalists in determining what should be reported or the answer of why this news is feasible or important to be publicized [4].

In this research, the researcher chose one of the online news portals in Indonesia that is Tribunnews.com as the object to be studied. Researchers chose this online news portal because based on www.alexa.com, news portal Tribunnews.com ranked one in Indonesia as an online news portal which is visited often by Indonesian people.

\section{A. Content Analysis}

Content analysis has a long history of communication; content analysis has been used since 4,000 years ago in ancient Rome. The use of content analysis continues to evolve of which the growth and development of the content analysis used in the last five decades can be seen in the table below [5] 
Table 1 content analysis used in the last five decades

\begin{tabular}{|l|l|}
\hline Year & Details \\
\hline The late 1940 & $\begin{array}{l}\text { 1. Research on changes in the } \\
\text { international political system by } \\
\text { looking at } 60 \text { editorials in five } \\
\text { world newspapers. } \\
\text { 2. Analyzing the first five hours of } \\
\text { news coverage on CNN, ABC, } \\
\text { CBS and NBC channels. }\end{array}$ \\
\hline $1980-1988$ & $\begin{array}{l}\text { Using articles in magazines, } \\
\text { researchers characterize public } \\
\text { image shifting from international } \\
\text { terrorism acts. }\end{array}$ \\
\hline $1980-2000$ & $\begin{array}{l}\text { Analyzing the probability samples } \\
\text { from 2,696 newspapers in the } \\
\text { United States }\end{array}$ \\
\hline $1995-2000$ & $\begin{array}{l}\text { Analyzing the contents of the social } \\
\text { problems topic. }\end{array}$ \\
\hline $1997-2000$ & $\begin{array}{l}\text { Projects for excellence in journalism } \\
\text { have undertaken a number of major } \\
\text { studies of news coverage by } \\
\text { exploring the impact of this type of } \\
\text { news ownership on television. }\end{array}$ \\
\hline
\end{tabular}

By using content analysis, we can analyze the existing messages in print, broadcast, and internet media systematically and objectively as well as see the cause and effect relationship between the content and viewers [6]. In addition, content analysis is also defined as a technique for knowing the content characteristics presented in the physical text of messages, prints, sounds and images [7]

\section{Click bait}

Click bait phenomenon which is spreading and popular among online media actually has an understanding which is a strategy used by online news portals mainly aiming to attract visitors to click on those web page links [8]. In order to find out whether a story uses a click bait or not, there are types of click bait [9]:

1. Exaggeration: the title exaggerates the content on the landing page.

2. Teasing: Removal of the details in the title to build tension.

3. Inflammatory: inappropriate use of phrases or words.

4. Formatting: Too much capital letters

5. Graphic: Obscene or intrusive or untrustworthy material.

6. Bait and switch: The promised/ implied title does not exist on the landing page: this requires additional clicks or just disappears.

7. Ambiguous: The title is vague or confusing which is then sparks a curiosity.

8. Wrong: wrong factual.

\section{News Value}

In making news, it is certainly important for a journalist to pay attention to news value. News value is the term which becomes the reference or important measure of the reporter or journalist in writing all the information in the news [10]. The news value used by W. Lippmann in his work entitled 'Public Opinion' are distance, personal interest, surprise, and conflict [11]. Basically, the design of news value category is very diverse. In this study, the researchers decided to use the design of news value based on Caple, Bednarek.

Inside news value consists of several elements of news value i.e [12]:

\section{Magnitude}

Something big in terms of numbers so it becomes something meaningful and interesting to many people.

\section{Actuality}

The news is related to time. It is related to the speed then it can be said media or newspapers have high news value if they are fast in conveying information.

\section{Distance}

Events that have an element of closeness to the reader in terms of physical geography, interests, talents, and professions which will attract attention.

\section{Famous}

Events involving people, figures, places known by the public have high news value.

\section{Impact}

The news value is related to the impact. The wider the impact in political, social and economic life, the higher the value contained in the news.

\section{Human Interest}

News has an appeal or touches one's feelings.

7. Tension

News that contains tense element for the audience.

8. Unconsciousness

News contains an unusual element or contains a strange element which attracts the reader.

\section{Conflict}

News that contains negative elements, disagreements.

10. Sex

News related or identical to women

11. Surprise

News of unexpected or sudden events.

12. Thorough

News must be made thoroughly and correctly. 


\section{New Media Theory}

Through digitization, internet will be everything and television, telephones, and computers will gather or integrate with the Internet. On the other hand, the presence of new media provides a much more active participation in the media. This is because the old-fashioned cosmos is more isolated, while consumers of the new media will be more connected because they can upload their own content and opt for wider fragmentation, including choosing which medium they will use [13]

\section{E. Research Question}

1. How many news value used by article which has click bait?

\section{METHODS}

This research uses Quantitative Content Analysis. Quantitative content analysis is a scientific research technique aims at knowing the characteristic description of the content and drawing the inference of the content [14].

Content analysis is intended to systematically identify the content of communication which is manifested and done objectively, valid, reliable, and replicable.

Type of research used in this research is descriptive research type. This descriptive content analysis is not intended to test a particular hypothesis or examine the relationship between the variables. This analysis only describes or illustrates the aspects and characteristics of a message [14].

This study consists of 8 steps. First, the researcher made the purpose of this content analysis. In this case, the researchers determine what the researchers want to know in the content analysis. Second, the researchers made the operationalization of the concept. Third, the researchers created a coding sheet. Fourth, the researchers determine the population and sample. Fifth, the researcher did training on coders and testing. Sixth, the researcher processed the coding. Seventh, the researchers calculated the results of the coding. Eighth, the researchers entered the data and did the analysis [14].

The data of this study is the article on website www.tribunnews.com, particularly in the celebrity column which uses the click bait phenomenon (August 2017-October 2017). The sampling of this research was conducted by taking three articles from each month. Thus, there are nine articles to be analyzed. The sampling was done through purposive and cluster sampling. The purposive sampling was done by sorting the articles from August 2017 until October 2017 in which the researchers took the article which uses click bait phenomenon only. After all the click bait articles were collected, then the process is continued by using cluster sampling. The cluster sampling process was done first by determining the cluster. In this process, the researchers grouped the articles by month. In the next step, the researchers take articles randomly from each month.

The data of this research is the article published in August at Tribunnews.com, particularly in the celebrity column. There are 1953 articles of which 203 articles use click bait phenomenon. Since the researcher will take each of the three samples from each month randomly, a calculation was done by the researchers to take the sample: $203: 3=67.6$ rounded to 68 . Therefore, the sample was obtained by making a draw between the numbers 1-68. The result of drawing shows the number of 15 so that the sample taken is article number 15,83 (multiples of 68), and 151. For the articles published in September, there are 1698 articles with 113 articles using click bait phenomenon. The sampling is 113: $3=37.6$ rounded to 38, and 86. For the article published in October, there are 1876 articles where 145 articles have click bait phenomenon, thus 145: $3=48.3$ rounded to 48 , and the draw obtained was the number of 22, 70 (multiple of 48), and 118.

\section{RESULT}

We can see on Article I that the highest categories are distance, famous, and conflict with $8.40 \%$ among seven categories in this article (Magnitude, actual, impact, tension, unconsciousness, sex, and thorough are $0 \%$ ).

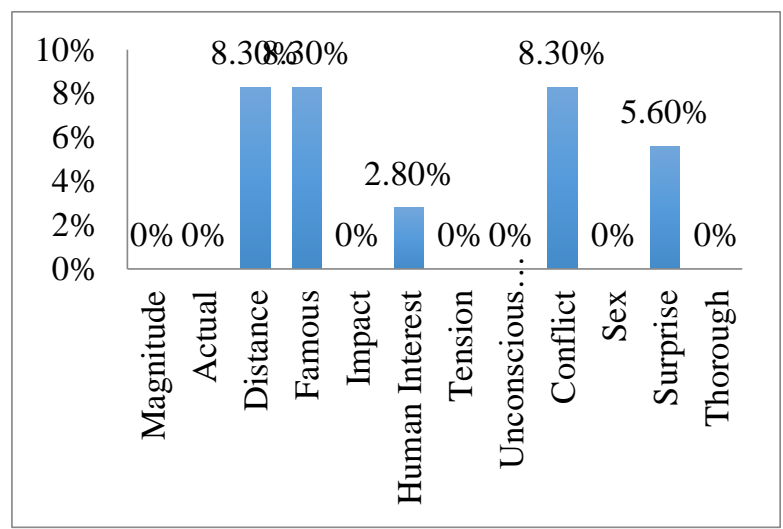

Figure 2 Results of News Value in Article I

Figure 3 represents about each category in news values of article 2 . There are only three categories with the same percentage $(8.30 \%)$. The three categories are distance, famous, and human interest.

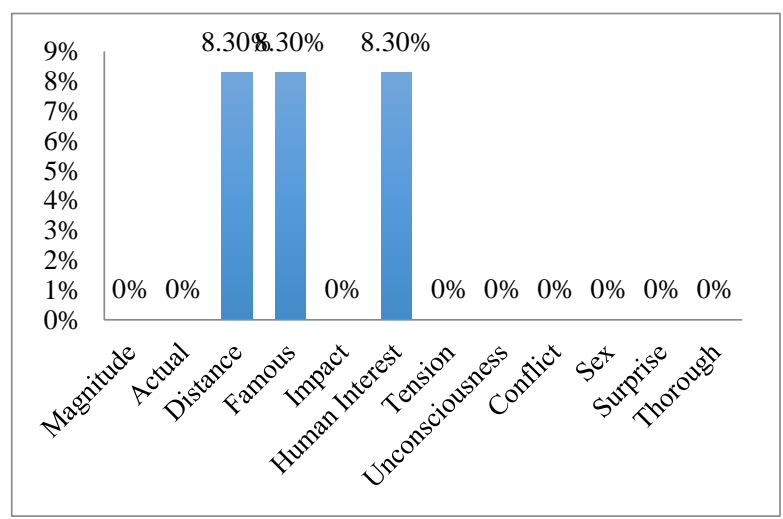

Figure 3 Results of News Value in Article II 
The highest categories in Article 3 are distance, famous, and human interest with $8.30 \%$. The other eight categories is not included in this article.

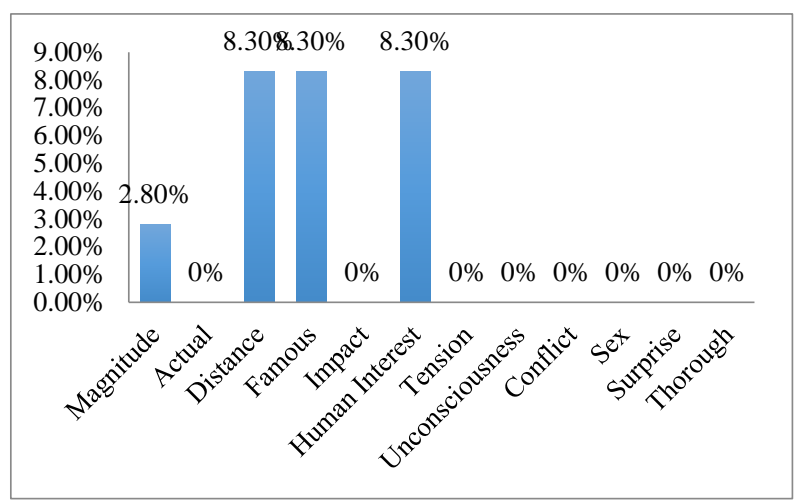

Figure 4 Results of News Value in Article III

In Article 4, the highest categories are actual and human interest with $8.30 \%$ and the other seven categories is not included in article 4.

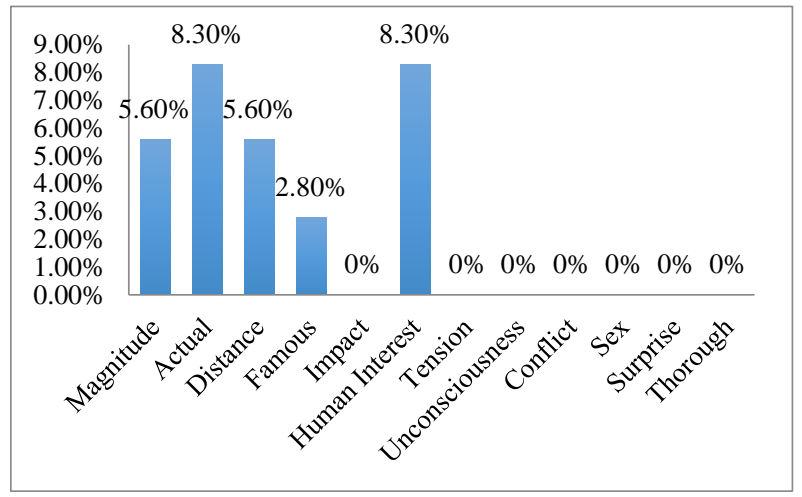

Figure 5 Results of News Value in Article 4

The highest categories in article 5 are distance, famous, and surprise with $8.30 \%$. The lowest categories are the other eight categories since they are not included in article 5.

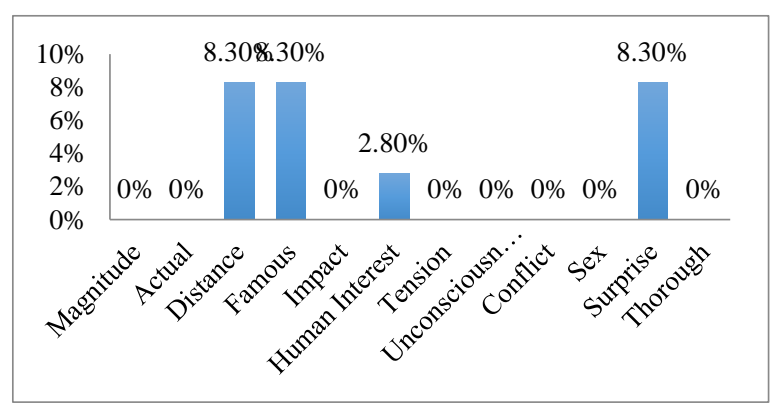

Figure 6 Results of News Value in Article 5
In Article 6, there are four categories included in this article, but the highest categories are actual, distance, and famous with $8.30 \%$. Eight categories are not included in this article.

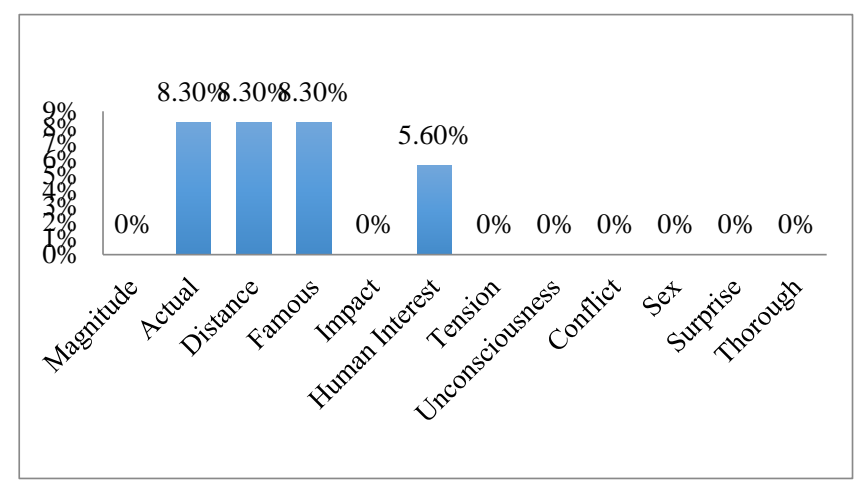

Figure 7 Results of News Value in Article 6

There are four categories included in article 7, but the highest categories are human interest and surprise with $8.30 \%$. The other eight categories are the lowest since they are not included in this article.

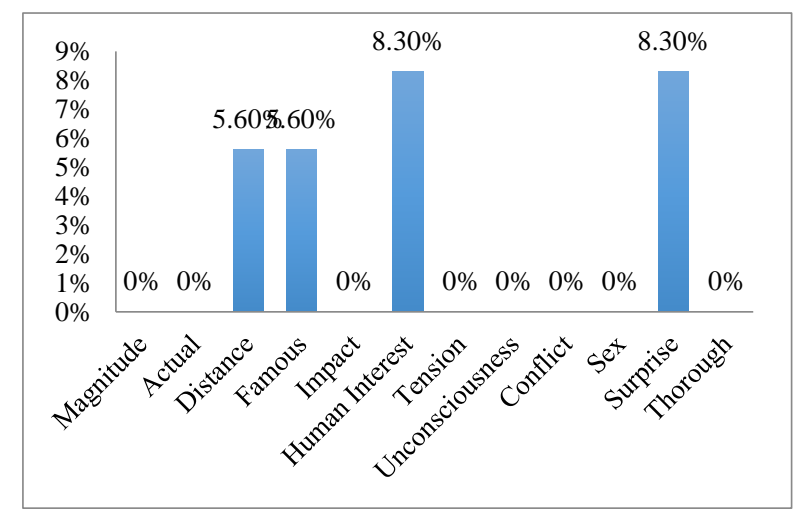

Figure 8 Results of News Value in Article 7

In article 8 , there are four categories included. They are actual, distance, famous, and human interest. However, the highest categories are actual, distance, and famous. The other eight categories are not included in this article making them as the lowest categories. 


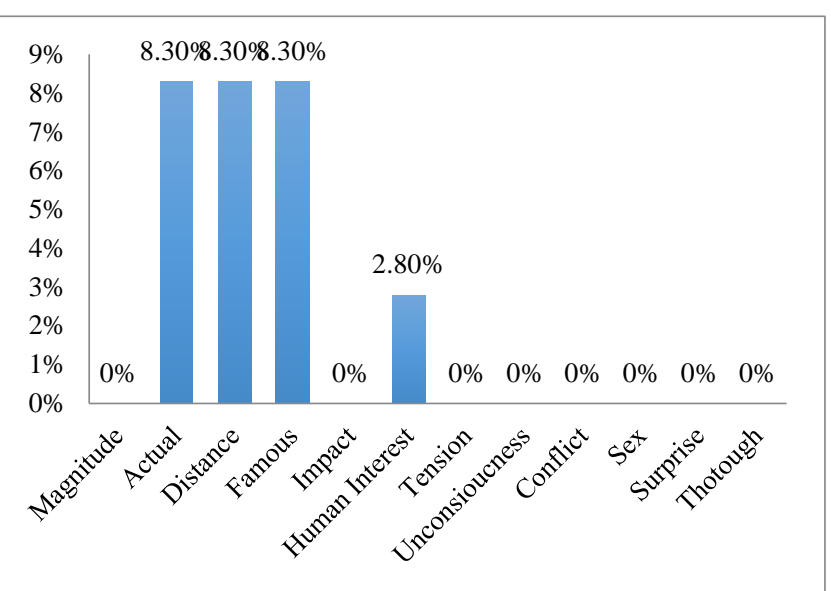

Figure 9 Results of News Value in Article 8

There are four categories included in this article, but the highest categories are distance, famous, and human interest with $8.30 \%$. The other eight categories are not included in this article, those are magnitude, actual, tension, unconsciousness, conflict, sex, surprise, and thorough.

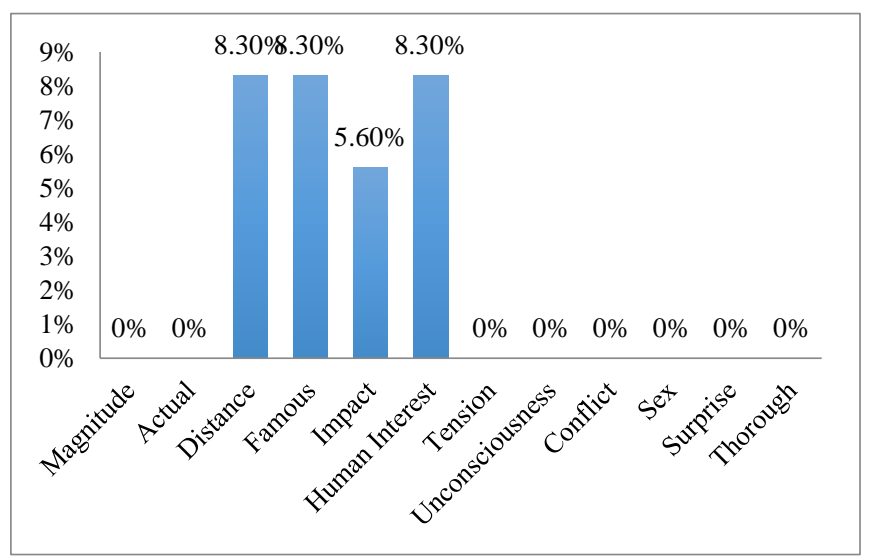

Figure 10 Results of News Value in Article 9

\section{CONCLUSION}

Based on the data, it can be concluded that through the calculation, it was found that from the nine articles studied, the use of news value category at most is in Article 1 (Distance, Introduction, Human Interest, Conflict, Surprise) and Article 4 (Magnitude, Distance, Introduction, Impact, Human Interest) since both use five categories of news value from twelve news value categories.

The conclusion of this research is that people always miss underestimate 'click bait' strategy. However, this research found out that news with 'click bait' do have news value. Thus, it means that even though many people think that the strategy of click bait encourages the assumption that journalists produce unimportant news, it is wrong. Even though journalist or media uses 'click bait' strategy, they still produce important news which still have values.

\section{REFERENCES}

[1] Schultz, D. E. (1997). Integrated marketing communications in U.S. advertising agencies: An exploratory study. Journal of Advertising Research , 37 (5), 9.

[2] Chen, Y., Conroy, N. J., \& Rubin, V. L. (2015). Misleading Online Content: Recognizing Clickbait as "False News". 15-19.

[3] Tudor, D. (2015). Now The Pipers Can Pick Their Own Tune. 26, 31-36.

[4] Caple, H., \& Bednarek, M. (2016). Rethinking nes values: What a discursive approach can tell us the construction of news discourse and news photography. 17(4), 435-455.

[5] Riffe, D., Lacy, S., \& Fico, F. G. (2005). Analyzing Media Messages. New Jersey, USA: Lawrence Erlbaum Associates.

[6] Neuendorf, K. A. (2002). The Content Analysis Guidebook. United States: Sage Publications.

[7] Eriyanto. (2011). Analisis Isi. Jakarta: Kencana.

[8] Chen, Y., Conroy, N. J., \& Rubin, V. L. (2015). Misleading Online Content: Recognizing Clickbait as "False News". 15-19.

[9] Biyani, P., Tsioutsiouliklis, K., \& Blackmer, J. (n.d.). "8 Amazing Secrets for Geting More Click":Detecting Clickbaits in News Stream Using Article Informality. 94-100.

[10] Sumadiria, A. H. (2008). Jurnalistik Indonesia. Indonesia: Sembiosa Rekatama Media.

[11] Gregus, L., \& Minarikova, J. (2016). News Values In Slovak Television News. Communication Today , 7 (2), 80-88.

[12] Caple, H., \& Bednarek, M. (2016). Rethinking nes values: What a discursive approach can tell us the construction of news discourse and news photography. $17(4), 435-455$.

[13] Littlejohn, S. W., \& Foss, K. A. (2009). Encyclopedia Of Communication Theory. USA: Sage Publications.

[14] Eriyanto. (2011). Analisis Isi. Jakarta: Kencana. 